\title{
ECOLOGY OF EIGHT SPECIES OF FRESHWATER OSTRACODS (CRLSTACEA) FROM QENA GOVERNORATE. UPPER EGYPT
}

\author{
Mohammad A. Hussein'; thmad H. Obuid-Allah '; \\ Amal A. Mahmoud ' and Heba Mohammad Fangary? \\ 1-Faculty of Science. Assiut University, Assiut. Egypt. \\ 2-Faculty of Science. South Valiey University. Qena. Upper Egypt.
}

Key words: Ecology, freshwater ostracods. Qena. Upper Egypt.

\begin{abstract}
The present work deals with the ecology of eight species of 1 freshwater ostracods (Cypridopsis viduca. Polamocypris variegata. Hemicypris dentatomarginata, llyocypris gibba, llyocypris. biplicata, Fabaeformiscandona holzkampfl. Pseadocandona semicognita and Limnocythere inopinata) collected from Qena Governorate. Monthly samples were collected for a period of one year (from July. 2000 till June, 2001) from four sites. Some ecological factors were measured during the period of investigation and correlated with the density of the ostracod species studied. Statistical analysis was performed by using SPSS software package (version 9) and the model equations controlling the density and the physical factors measured for the studied species were deduced.
\end{abstract}

\section{INTRODUCTION}

Ostracods are small bivalved crustaceans. Their calcified carapaces have an average length of $1 \mathrm{~mm}$. and completely envelop the reduced body (Martens et al., 1996). Horne (1983); Martens et al. (1985); Geiger (1990a and b), and Martens \& Tudorancea (1991) indicated that quantitative studies on seasonality, life history and distribution of freshwater ostracods are scarce. Some studies were concerned with the distribution of freshwater ostracods as those of Martens \& Toguebaye (1985); Martens \& Tudorancea (1991); Rieradevall \& Roca (1995) and Martens (1998). Other studies were dealing with the relation between freshwater ostracods and environmental factors. These include Martens (1985, 2000); Latifa 
(1987); Santamaria el al. (1992); Roca et al. (1993); Roca \& Wansard (1997) and Yin et al. (1999).

In Egypt, to the best of the present author's knowledge, studies of freshwater ostracods did not gain the attention they deserve, although they play an important role in the freshwater ecosystem. Klintz (1907) reported Cypris sculpta from the Nile, but the genus can not be identifjed with certainty from his paper. Also Daday (1910) described a new genus and six new species from Egypt. His monumental work had no details of the described species and the names of some genera had been changed.

The present paper is meant to contribute to the knowledge of taxonomy and ecology of this neglected crustacean group.

\section{MATERIAL AND METHODS}

Monthly samples were collected during one year (from July, 2000 till June. 2001) from four sites at Qena Governorate including the following freshwater irrigation canals: 1- El-Twarat canal $\left(26^{\circ} 7^{\prime}\right.$ N/ $\left.32^{\circ} 41^{\prime} \mathrm{E}\right)$. II- El-Taramsa canal ( $\left.26^{\circ} 8^{\prime} \mathrm{N} / 32^{\circ} 40^{\prime} \mathrm{E}\right)$, III- Faw Bahary canal $\left(26^{\circ} 8^{\prime} \mathrm{N} / 32^{\circ} 24^{\prime} \mathrm{E}\right)$, and IV-Hagaza canal $\left(25^{\circ} 51^{\prime} \mathrm{N} /\right.$ $32^{\circ} 48^{\prime}$ E). For quantitative samples, an iron cuboidal sampler, with open ends, measuring $30 \times 30 \times 60 \mathrm{~cm}$. was used. The sampler was applied to enclose a column of known volume of water. Three replicates of samples were applied at each collection. The relative density of each species was calculated as the number of specimens present in the whole volume of the sampler. Ecological factors measured included air and water temperatures. dissolved oxygen. $\mathrm{pH}$ and conductivity. Statistical analysis was performed by using SPSS software package (version 9).

\section{RESULTS}

1- Dominance levels of the studied species:

In the present study, 2324 specimens were collected from the eight different species studied during the whole period of investigation. The most dominant species was Cypridopsis vidua (Sp.1). from which 826 specimens were collected. constituting 35.5 $\%$ of the rotal catch. followed by Ilyocypris biplicata (Sp.5) $(626$ specimens) constituting $26.9 \%$. followed by Pseudocandona semicognita (Sp.7) (339 specimens) constituting 14.6\%. then 
Hemicypris clensutomerginata (Sp.3) (23+ specimens) constituting 10.1\%. followed by llyocipris gibba (Sp. H) (137 specimens) constituting $5.9 \%$. then Limmocythere inopinulu (Sp.8) 193 specimens) constituting $+\%$. followed by Poramocypris varicegata (Sp.2) (65 specimens) constituting $2.8 \%$ and Fubueformiscanclona holzkumpti (Sp.6) It specimens) constituting $0.17 \%$ of the total catch. (Table 1).

\section{2-Seasonal variations:}

Generally, the total catch of the eight species showed its maximal value in Autumn (792 specimens. constituting $3+.1 \%$ ). followed by Winter ( 781 specimens constituting $33.6 \%$ ). then Spring ( 440 specimens. representing $18.9 \%$ ). whereas the least catch was recorded in Summer (311 specimens, constituting 13.4\%) (Table 1).

\section{3- Statistical analysis of the relative density of recorded species:}

Applying the MANOVA test for the relative density of the species collected during the period of investigation, as dependent variables and the sites of collection. as independent variables (Table 2). revealed that the majority of differences were highly significant $(\mathrm{P}<0.01)$, but for Fabaeformiscandona holzkampfi and Pseudocandona semicognita were insignificant.

Applying the above mentioned test using the seasons as independent variables. it was found that the majority of differences were insignificant except for llyocypris biplicuta that was highly significant while Hemicypris dentatomarginata and Limnocythere inopinata was significant. On using both sites and seasons as independent variables. it was concluded that llyocypris biplicata. Hemicypris dentatomarginata, Potamocypris variegata and Limnocythere inopinata were highly significant different, Cypridopsis vidua and Pseudocandona semicognita were significantly different and Ilyocypris gibba and Fabaeformiscandona holzkampfi were insignificantly different.

\section{4- Correlation between the environmental factors and the relative} density of the recorded species:

$B \dot{y}$ applying the correlation analysis between the relative densities of ostracod species with the ecological factors during the period of investigation (Table 3), it was concluded that: 
1- The relative density of Cypridopsis vidua was negatively correlated with water temperature and positively correlated with dissolved oxygen.

2- The relative density of Potamocypris variegata was positively correlated with Ilyocypris gibba.

3- The relative density of Hemicypris dentatomarginata was positively correlated with Limnocythere inopinata and negatively correlated with dissolved oxygen.

4- The relative density of llyocypris gibba was positively correlated with Potamocypris variegata and negatively correlated with conductivity.

5- The relative density of Ilyocypris biplicala was positively correlated with $\mathrm{pH}$.

6- The relative density of Fabaeformiscandona holzkampfi was positively correlated with conductivity.

7- The relative density of Limnocythere inopinata was positively correlated with Hemicypris dentatomarginata and negatively correlated with dissolved oxygen.

On applying Stepwise multiple regression to select a model where all variables are significant (Table 4), it was concluded that:

1- The relative density of Cypridopsis vidua was affected by dissolved oxygen and water temperature. The model equation was : Relative density of animal in $54000 \mathrm{~cm}^{3}=-536.62+39.49$ dissolved oxygen +10.81 water temperature

2- The relative density of Hemicypris dentatomarginata was affected by dissolved oxygen and air temperature. The model equations was: Relative density of animal in $54000 \mathrm{~cm}^{3}=56.07-4.05$ dissolved.oxygen -0.77 air temperature

3- The relative density of Ilyocypris gibba was affected by conductivity. The model equation was: Relative density of animal in $54000 \mathrm{~cm}^{3}=16.21-42.82$ conductivity

4- The relative density of /lyocypris biplicara was affected by $\mathrm{pH}$. The model equation was: Relative density of animal in $54000 \mathrm{~cm}^{3}=$ $452.7 \hat{3}+62.5 \mathrm{pH}$

5- The relative density of Fabaeformiscandona holzkampfi was affected by conductivity. The model equation was: Relative density of animal in $54000 \mathrm{~cm}^{3}=-1.001+3.52$ conductivity 
6- The relative density of Limnocythere inopinata was affected by dissolved oxygen. The model equation was: Relative density of animal in $54000 \mathrm{~cm}^{3}=9.39-0.95$ dissolved oxygen

\section{DISCUSSION}

From the present results. it is evident that both Autumn and Winter were the most suitable seasons for the recorded ostracod species. whereas Spring and Summer were less favorable for these animals. Species (1) (Cypridopsis vidua). Sp.(5) (Ilyocypris biplical(s) and Sp.(7) (Pseudocandona semicognita) exhibited the same general trend, and these species constituted $77 \%$ of the total catch. On the other hand, Sp.(2) (Potamocypris variegata). Sp. (3) (Hemicypris dentatomarginata). Sp.(4) (Ilyocypris gibba) and Sp.(8) (Limnocythere inopinata) were most abundant during Spring and Summer. Species (6) (Fabaeformiscandona holzkampfi) could be neglected: since four specimens only were recorded during the whole period of investigation. The higher value during Autumn is attributed to the higher value of the species Cypridopsis vidua and Pseudocandona semicognita. In Winter, the higher value is attributed to Ilyocypris biplicala (Table 1). Mezquita et al. (1999) studied the ecology and distribution of ostracods associated with flowing waters in the Eastern Iberian Peninsula during Autumn and Spring and concluded that no clear patterns were observed on the seasonality of common species. However. they found Eucypris virens and Trajancypris clavata only in the Spring months. Baltanas (1994) regarded the first species as a Winter-Spring form, while the second species was regarded by Martens (1989) as a Spring-Summer species. In the present study, it was observed that Fabaeformiscandona holskampfi was represented only in Winter and Spring, while the other seven species were represented during all seasons. Cohen \& Morin (1990) recorded that peak numbers usually occur in warm seasons and only occasionally in late fall or Winter. On the contrary, Rieradevall \& Roca (1995) observed that Candona neglecta and Darwinula stevensoni showed a tendency towards maximum densities when temperature were low, while other species such as lsocypris beauchampi, Cypridies torosa and Cyclocypris ovum seem to tolerate warmer water.

Roca and Wansard (1997) indicated that the temperature has a strong impact on the development and survival rates of ostracods. For 
Herpetocypris brevicaudata, $15-19^{\circ} \mathrm{C}$ constitutes a threshold, below which calcification of the valves and survival rates significantly decrease. Other species adapted to high latitude or high altitude may tolerate very low temperature (Delorme, 1991). In contrast, a species of Polamocypris has been found in hot springs that ranged from 30 to $54^{\circ} \mathrm{C}$ (Wickstrom \& Castenholz, 1973).

Concerning the collected species during the present study, one can conclude that Cypridopsis vidua and Ilyocypris biplicata constituted the highest percentage of the total ostracods collected (35.5\% and $26.9 \%$, respectively) (Table 1). This result is in accordance with many investigators concerning species Cypridopsis vidua, where it seems to be a cosmopolitan and highly tolerant species (Meisch \& Broodbakker, 1993; Beyer \& Meisch, 1996 ; Beyer et al., 1997). The present study indicated that Cypridopsis vidua is positively correlated with water temperature. This may help the species to tolerate higher temperatures and may account for its cosmopolitan distribution.

The present results showed a positive correlation between the $\mathrm{pH}$ and the relative density of Ilyocypris biplicata and that all sites were nearly neutral (Tables 3. 4). This result supports the view of Dole-Olivier ef al. (2000) who indicated that ostracods generally live in circumneutral water. with a readily available source of Calcium Carbonate. because of their calcareous carapaces. The positive correlation of the above mentioned species with $\mathrm{pH}$ may give it an advantage to resist high $\mathrm{pH}$ values and may account for its cosmopolitan distribution. On the contrary, Delorme (1991) indicated that some species have a very broad $\mathrm{pH}$ range $(5.4-13$ such as Candona candida).

The present investigation indicated that Hemicypris dentatomarginata and Limmocythere inopinata are negatively correlated with dissolved oxygen. while Cypridopsis vidua is positively correlated (Tables 3. 4). This result is in accordance with that of Dole-Olivier et al. (2000) who stated that most ostracods can survive a wide range of dissolved oxygen concentrations and species that live in shallow muddy ponds may tolerate very low oxygen supply. like some Canadian ostracods which have been found near zero concentrations such as Candona candida and Cypria ophthalmica (Delorme. 1991). Heterocypris incongruens can tolerate anaerobic conditions for at least 2 weeks. 
The present study indicated that the wo species llyocypris: gibba and Potanocypris varieguta are positively correlated to each other (Table 3). This result agrees with that of Mezquita et al. (1999) who studied the species associations and species environment relationships and concluded that the two mentioned species were clustered together in the same group.

\section{REFERENCES}

Baltanás. A. (1994). Taxonomy and ecology of Eucypris rirens (Ostracoda. Cyprididae). In: D. Horne and K. Martens. eds.. The evolutionary ecology of reproductive modes in nonmarine Ostracoda. Greenwich University Press. London. England, pp. 9-16.

Beyer. G. and Meisch. C. (1996). Freshwater Ostracoda (Crustacea) collected on La Gomera (Canary Islands). with a redescription of Cypridopsis obesa (Brady \& Robertson. 1869). Trav. sci. Mus. nat. hist. nat. Lux., 23: 29-56.

Beyer, G., Meisch. C. and Wouters. K. (1997). New records of freshwater Ostracoda (Crustacea) from La Gomera, El Hierro, Fuerteventura and Tenerife (Canary Islands). Bull. Soc. Nat. Luxemb., 98: 239-259.

Cohen. A. C. and Morin, J. G. (1990). Patterns of reproduction in ostracods: a review. J. Crustacean Biol., 10: 184-211.

Daday, E. V. (1910). Ergebnisse der mit Subvention aus der Erbschaft Treitl unternommenen zoologischen Forschungsreise Dr. Franz Werner's nach dem ägyptischen Sudan Nord-Uganda. 15. Beiträge zur Kenntnis der Mikrofauna des Nils. Sitzungsber. K. Akad. Wiss. Math. Naturwiss. K1. (Wien), 119: 573-589.

Delorme, L. D. (1991). Ostracoda. Ecology and classification of North-American Freshwater Invertebrates. (Eds. J. B. Thorp and A. P. Covich), pp. 691-722. Academic Press, New York. 
Dole-Olivier, M. J. ; Galassi, D. M. P. ; Marmonier, P. and Creuzé des Châtelliers, M. (2000). The biology and ecology of lotic microcrustaceans. Freshw. Biol., 44: 63-91.

Geiger, W. (1990a). Field and laboratory studies on the life cycle of Cytherissa lacustris (Sars) (Crustacea, Ostracoda) with special emphasis on the role of temperature. Bull. Inst. Gol. Bassin d'Aquitaine, 47: 191-208.

Geiger, W. (1990b). The role of oxygen in the disturbance and recovery of the Cytherissa lacustris population of Mondsee (Austria). Bull. Inst. Gol. Bassin d'Aquitaine, 47: 167-189.

Horne, D. J. (1983). Life- cycles of podocopid ostracoda - a review (with particular reference to marine and brackish water species). In: Maddocks R. (ed.), Applications of Ostracoda.. Proceedings of the Eight International Symopsium on Ostracoda, July 26-29. 1982. University of Houston: 581589.

Klintz. J. H. (1907). Über eine neue Cypris-Art aus dem Nil. Arch. Hydrobiol. Planktonk, 3: 274-289.

Latifa. G. A. (1987). Effect of temperature on the development of embryonic and postembryonic stages of Heterocypris incongruens (Ramdohr. 1808) (Ostracoda). Crustac.. 52(1): 95-99.

Martens. K. (1985). Effects of temperature and salinity on postembryonic growth in Myrilocypris henricae (Chapman) (Crustacca. Ostracoda). Jour. of Crustac. Biol:. 5(2): 258272.

Martens. K. (1989). On the systematic position of the Eucypris clarala-group. with a description of Trajancypris gen. nov. (Crustacea. Ostracoda). Archiv für Hydrobio.. 83: 227-251. 
Martens, K. (1998). Diversity and endemicity of recent non- marine ostracods (Crystacea. Ostracoda) from Africa and South America: a faunal comparison. Verh. Internat. Verein. Limnol., 26: 2093-2097.

Martens, K. (2000). Factors affecting the divergence of mate recognition systems in the Limnocytherinae (Crustacea, Ostracoda). Hydrobiol., 419: 83-101.

Martens, K. ; Davies, B. R. ; Baxter, A. J. and Meadows, M. E. (1996). A contribution to the taxonomy and ecology of the Ostracoda (Crustacea) from Verlorenvlei (Western Cape. South Africa). S. Afr. J. Zool., 3l(1): 23-36.

Martens, K. ; Deckker, P. D. and Marples, T. G. (1985). Life history of Mytilocypris henricae (Chapman) (Crustacea, Ostracoda) in lake Bathurst, New South Wales. Aust. J. mar. Freshwat. Res., 36: 807-819.

Martens, K. and Toguebaye, B. S. (1985). On the presence of Cypris subglobosa Sowerby, 1840 (Crustacea, Ostracoda) in Africa. with notes on the distribution of this species. Annls Soc. $r$. zool. Belg. T.. 115(2): 147-153.

Martens, K. and Tudorancea. C. (1991). Seasonality and spatial distribution of the ostracods of lake Zwai. Ethiopia (Crustacea: Ostracoda). Freshwa. Biol.. 25: 233-24]

Meisch. C. and Broodbakker. N. W. (1993). Freshwater Ostracoda (Crustacea) collected by Prof. J. H. Stock on the Canary and Cape Verde islands. With an annotated checklist of the Freshwater Ostracoda of the Azores. Madeira. the Canary. the Selvagens and Cape Verde islands. Trav. sci. Mus. nat. hist. nat. Lux.. 19: 3-47

Mezquita. F. : Griffiths. H. I. : Sanz. S. : Soria. J. M. and Piũón. A. (1999). Ecology and distribution of ostracods associated with flowing waters in the Eastern Iberian Peninsula. Jour. of Crust. Biol.. 19(2): 344-354. 
Rieradevall. M. and Roca. J. R. (1995). Distribution and population dynamics of ostracods (Crustacea. Ostracoda) in a karstic lake: Lake Banyoles ( Catalonia. Spain). Hydrobiol.. 310: 189-196.

Roca. J. R. ; Baltanás. A. and Uiblein. F. (1993). Adaptive responses in Cypridopis vidua (Crustacea. Ostracoda) to food and shelter offered by a macrophyte (Chara fragilis). Hydrobiol.. 362: 127-131.

Roca. J. R. and Wansard, G. (1997). Temperature influence on development and calcification of Herpetocypris brevicatidala Kaufmann. 1900 (Crustacea. Ostracoda) under experimental conditions. Hydrobiol., 347: $91-95$.

Santamaria. L. ; Balsa. J. ; Bidondo, B. ; Baltanás, A. and Montes, C. (1992). Salinity tolerance of three ostracode species (Crustacea, ostracoda) of Iberian saline lakes. Hydrobiol., 246: 89-98.

Wickstrom, C. E. and Castenholz, R. W. (1973). Thermophilic ostracods: aquatic metazoan with the highest known temperature tolerance. Science, 181:1063-1064.

Yin, Y. ;'Geiger, W. and Martens, K. (1999). Effect of genotype and environment on phenotypic variability in Limnocythere inopinata (Crustacea, Ostracoda). Hydrobiol., $400: 85-114$. 


\section{Abbreviations used in the tables}

Sp. 1: Cypridopsis vidua

Sp. 2: Potamocypris variegala

Sp. 3: Hemicypris dentantomarginata

Sp. 4: llyocypris gibba

Sp. 5: Ilyocypris biplicata

Sp. 6: Fabaeformiscandona holzkampfi

Sp. 7: Pseudocandona semicognira

Sp. 8: Liminocythere inopinata 


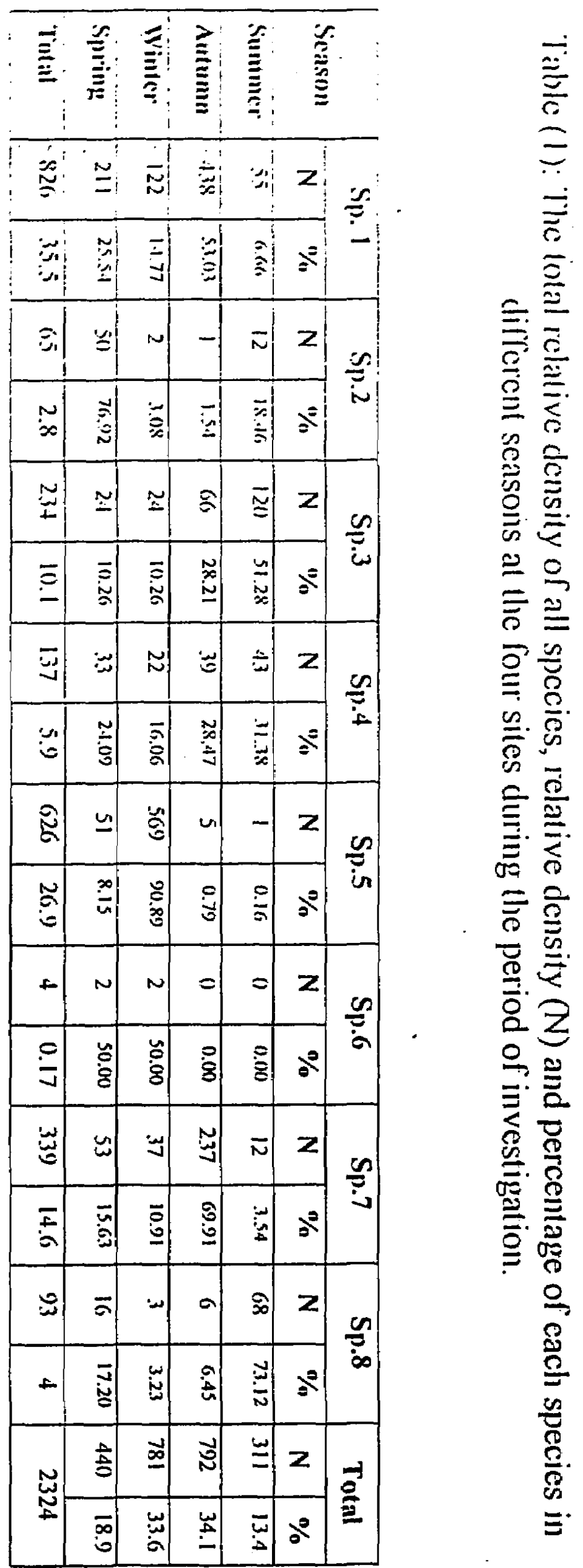


Table (2): MANOVA for different species and ecological factors for the four sites during the four seasons.

\begin{tabular}{|c|c|c|c|c|c|c|}
\hline Source & $\begin{array}{l}\text { Dependent } \\
\text { Variable }\end{array}$ & Sum of Squares & or & Mean Square & $\mathbf{F}$ & Sig. \\
\hline \multirow[t]{14}{*}{ SITES } & Total R.D. & 82176.854 & 3 & 27392.285 & 4.124 & .008 \\
\hline & Sp.1 & 92217.806 & 3 & 30739.269 & 11.252 & .000 \\
\hline & Sp. 2 & 752.083 & 3 & 250.694 & 5.071 & .002 \\
\hline & Sp.3 & 6796.188 & 3 & 2265.396 & 12.585 & .000 \\
\hline & Sp.4 & 2785.333 & 3 & 928.444 & 30.385 & .000 \\
\hline & Sp. 5 & 65347.299 & 3 & 21782.433 & 8.569 & .000 \\
\hline & Sp.6 & 2.250 & 3 & .750 & 2.298 & .081 \\
\hline & Sp.7 & 7157.076 & 3 & .2385 .692 & 2.109 & :102 \\
\hline & Sp.8 & 1304.250 & 3 & 434.750 & 5.587 & .001 \\
\hline & Air temp. & 787.187 & 3 & 262.396 & 17.696 & .000 \\
\hline & Water temp. & 202.850 & 3 & 67.617 & 11.545 & .000 \\
\hline & $\mathrm{pH}$ & .249 & 3 & $8.285 E-02$ & .1 .623 & .187 \\
\hline & $\mathrm{DO} 2$ & 39.369 & 3 & 13.123 & 13.946 & .000 \\
\hline & Cond. & $1.912 E-02$ & 3 & $6.373 \mathrm{E}-03$ & 13.550 & .000 \\
\hline \multirow[t]{14}{*}{ SEASON } & Total R.D. & 45148.965 & 3 & 15049.655 & 2.266 & .084 \\
\hline & $S p .1$ & 20902.472 & 3 & 6967.491 & 2.550 & .059 \\
\hline & Sp.2 & 406.972 & 3 & 135.657 & 2.744 & .046 \\
\hline & Sp.3 & 1570.299 & 3 & 523.433 & 2.908 & .037 \\
\hline & Sp.4 & 60.667 & 3 & 20.222 & .662 & .577 \\
\hline & Sp. 5 & 57078.854 & 3 & 19026.285 & 7.485 & .000 \\
\hline & Sp.6 & 1.361 & 3 & .454 & 1.390 & .249 \\
\hline & Sp.7 & 8007.910 & 3 & 2669.303 & 2.360 & .075 \\
\hline & Sp.8 & 702.306 & 3 & 234.102 & 3.009 & .033 \\
\hline & Air temp. & 3850.188 & 3 & 1283.396 & 86.551 & .000 \\
\hline & Water temp. & 2456.325 & 3 & 818.775 & 139.801 & .000 \\
\hline & $\mathrm{pH}$ & 4.190 & 3 & 1.397 & 27.353 & .000 \\
\hline & $\mathrm{DO} 2$ & 291.174 & 3 & 97.058 & 103.147 & .000 \\
\hline & Cond. & $6.188 \mathrm{E}-04$ & 3 & $2.063 E-04$ & .439 & .726 \\
\hline
\end{tabular}


Table (2): Continued

\begin{tabular}{|c|c|c|c|c|c|c|}
\hline Source & $\begin{array}{c}\text { Dependent } \\
\text { Variable }\end{array}$ & $\begin{array}{l}\text { Sum of } \\
\text { Squares }\end{array}$ & of & Mean Square & $F$ & Sig. \\
\hline \multirow{14}{*}{$\begin{array}{l}\text { SITES* } \\
\text { SEASONS }\end{array}$} & Total R.D. & 292620.729 & 9 & 32513.414 & 4.894 & .000 \\
\hline & Sp.1 & 60454.806 & 9 & 6717.201 & 2.459 & .013 \\
\hline & Sp.2 & 1220.917 & 9 & 135.657 & 2.744 & .006 \\
\hline & Sp.3 & 6219.229 & 9 & 691.025 & 3.839 & .000 \\
\hline & Sp.4 & 222.889 & 9 & 24.765 & .814 & .607 \\
\hline & Sp.5 & 176222.507 & 9 & 19580.279 & 7.703 & .000 \\
\hline & Sp.6 & 3.250 & 9 & .361 & 1.106 & .363 \\
\hline & Sp. 7 & 24803.896 & 9 & 2755.988 & 2.436 & .014 \\
\hline & Sp.8 & 2038.972 & 9 & 226.552 & 2.912 & .004 \\
\hline & Air kemp. & 398.563 & 9 & 44.285 & 2.987 & .003 \\
\hline & Water temp. & 123.025 & 9 & 13.669 & 2.334 & .018 \\
\hline & $\mathrm{pH}$ & 2.786 & 9 & .310 & 6.062 & .000 \\
\hline & $\mathrm{DO} 2$ & 10.457 & 9 & 1.162 & 1.235 & .280 \\
\hline & Cond. & $3.601 E-02$ & 9 & 4.001E-03 & 8.506 & .000 \\
\hline \multirow[t]{14}{*}{ Error } & Total R.D. & 850291.111 & 128 & 6642.899 & & \\
\hline & Sp.1 & 349696.222 & 128 & 2732.002 & & \\
\hline & Sp.2 & 6327.333 & 128 & 49.432 & & \\
\hline & Sp.3 & 23040.222 & 128 & 180.002 & & \\
\hline & Sp.4 & 3911.111 & 128 & 30.556 & & \\
\hline & Sp.5 & 325384.000 & 128 & 2542.062 & & \\
\hline & Sp.6 & 41.778 & 128 & .326 & & \\
\hline & $-S p .7$ & 144805.556 & 128 & 1131.293 & & \\
\hline & Sp.8 & 9959.778 & 128 & 77.811 & & \\
\hline & Air temp. & 1898.000 & 128 & 14.828 & & \\
\hline & Water temp. & 749.660 & 128 & 5.857 & & \\
\hline & $\mathrm{pH}$ & 6.536 & 128 & $5.106 \mathrm{E}-02$ & & \\
\hline & $\mathrm{DO} 2$ & 120.444 & 128 & .941 & & \\
\hline & Cond. & $6.020 E-02$ & 128 & $4.703 E-04$ & & \\
\hline
\end{tabular}


zo

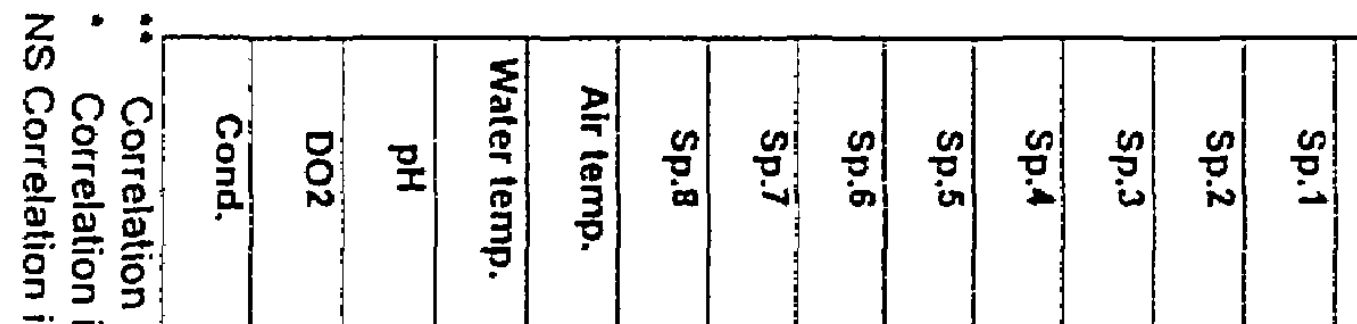

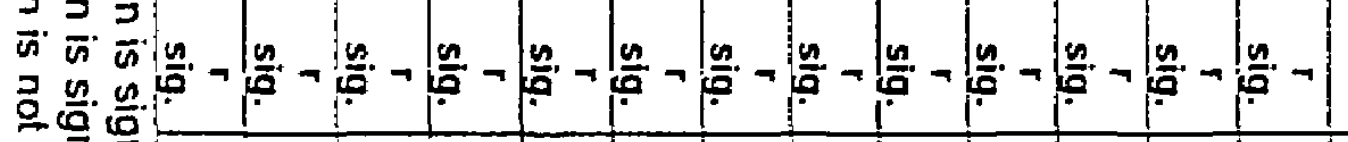

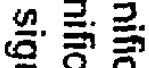

吾导罗

递哭

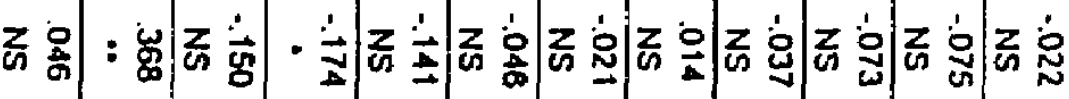

宁

蒠

웅ㅇ

要

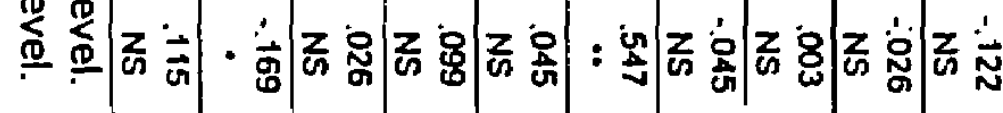

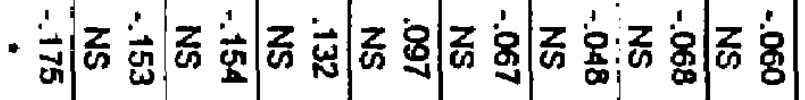

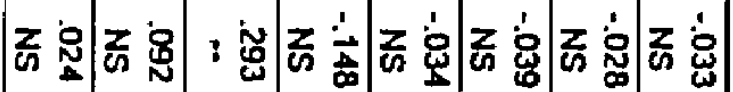

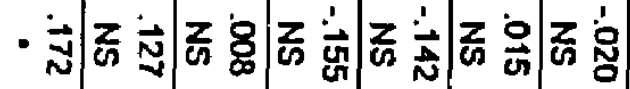

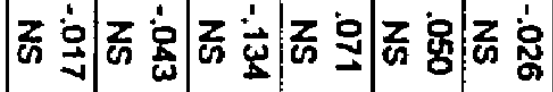

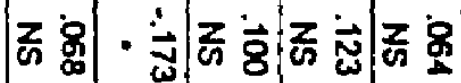

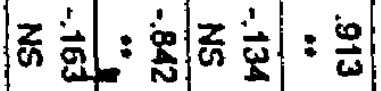

• 离 :

is 8 i

모 $\stackrel{0}{\overline{0}}$

종

: 